\title{
Somogy megye Athericidae katalógusa (Diptera: Athericidae)
}

\author{
MAJer JÓZSEF
}

MAJER J.: Checklist of Athericidae of Somogy county (Diptera: Athericidae)

Abstract: The family Athericidae was recently created by STUCKENBERG (1973). The position of the generas and some species is uncertain in this group. One species is known from the Somogy county, another one can be expected.

\section{Bevezetés}

A családot 1973-ban Stuckenberg különítette le a Rhagionidae családtól. Ma inkább a Tabanidae családdal hozzák közelebbi rokonságba. Az ide tartozó 5 nemzetség mindegyikébe csak néhány faj tartozik. Így a Palearktikumból öszszesen 15 fajuk ismert, bár Rokošný feltételezi, hogy ez a szám egy alapos átfogó revízió esetén akár 20 is lehet. A legnagyobb európai gyújtemények többségét (Berlin, Varsó) átvizsgálva, még a leírt 5 genusból az Atherix és Atrichops, valamint az Ibisia genusok közötti különbségek sem egyértelmúek, így a genusok léte is vitatható. Sajnos a problémák megoldásául szolgáló legfontosabb (és valószínúleg egyben leggazdagabb) gyứjtemény Budapesten az Allattárban volt, ami 1956-ban elégett. Hazánkban 2 faj fordul elő (MAJER, 1977), ezek közül egy Somogy megyéból is elókerült. A térség számtalan olyan vizes élöhellyel rendelkezik, ahol a másik faj is elófordulhat. Elöszeretettel rakják a petéiket a vizek fölé hajló levelekre, de még inkább hidak víz feletti mennyezetére.

\section{A Somogyból ismert faj}

\section{Athericidae}

Atherix marginata (Fabricius, 1781)

Majer, J.

1. táblázat: Somogyból ismert fajok száma

\begin{tabular}{|l|c|}
\hline Rend, Család & Fajszám \\
\hline Diptera & \\
\hline Athericidae & $\mathrm{I}$ \\
\hline
\end{tabular}




\title{
Irodalom
}

MAJER, J., 1977: Katonalegyek - Gömblegyek. Fauna Hungariae Akadémiai Kiadó, XIV/10. p. 75.

\section{Checklist of Athericidae of Somogy county (Diptera: Athericidae)}

\section{JÓZSEF MAJER}

The generic characters of Athericidae family have been elucidated by StuCKenberg (1973). The Palaearctic species belong to 5 genera at least. 2 species are known in Hungary, one of them was captured in Somogy county too. The other one, which lays its eggs underneath bridges above springs and rivers or on vegetation overhanging water, can be expected in the area since the county is rich in these preferred sites.

\author{
Author's address: \\ Dr. József MAJER \\ Department of General and Applied Ecology \\ University of Pécs \\ H-760l Pécs \\ Ifjúság útja 6. \\ HUNGARY
}

